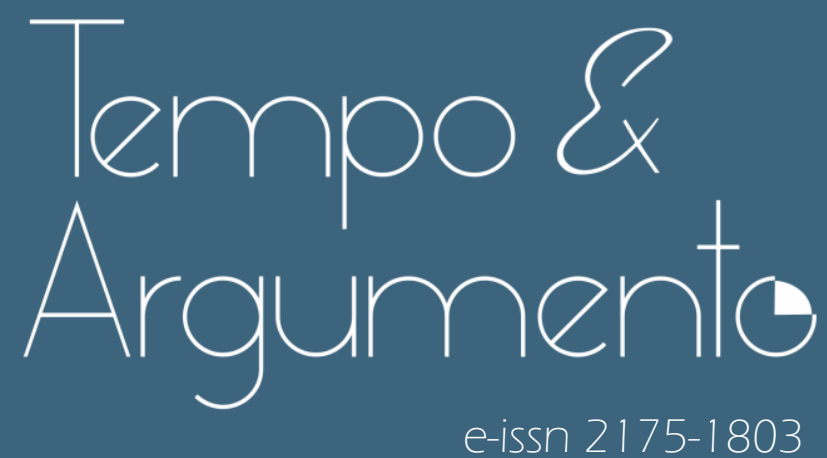

Nas tecituras do trabalho operário: a produção têxtil e a vida incerta na Fábrica Carmen em Fernão Velho - AL (anos $1940-1960)$

- Marcelo Góes Tavares

Doutor em História pela Universidade Federal de Pernambuco (UFPE ).

Professor da Universidade Estadual de Alagoas (UNEAL).

Palmeira dos Índios, AL - BRASIL

lattes.cnpq.br/2926035020378320

marce_goes@hotmail.com

(D) orcid.org/0000-0002-4843-4807

Para citar este artigo:

TAVARES, Marcelo Góes. Nas tecituras do trabalho operário: a produção têxtil e a vida incerta na Fábrica Carmen em Fernão Velho - AL (anos 1940 - 1960).

Tempo e Argumento, Florianópolis, v. 12, n. 30, e0 105, maio/ago. 2020.

doi $h$ ttp://dx.doi.org/10.5965/2175180312302020e0 105

Recebido: 27/09/2019

Aprovado: 03/06/2020 


\title{
Nas tecituras do trabalho operário: a produção têxtil e a vida incerta na Fábrica Carmen em Fernão Velho - AL (anos 1940 - 1960)
}

\begin{abstract}
Resumo
Este artigo traz como proposta, narrar a experiência histórica do trabalho operário no ramo têxtil em Fernão Velho, Alagoas. Essa localidade faz parte de um território fabril formado pela Fábrica Carmen, outrora Companhia União Mercantil, e sua vila operária. Nessa narrativa, são recuperados historicamente a produção têxtil, o trabalho operário, as condições de trabalho na fábrica, as representações de classe, e movimentos de resistência de trabalhadores. Como corpus documental, são utilizados relatos de operários registrados através da metodologia da história oral, relatórios da fábrica publicados no diário oficial de Alagoas, fotografias, processo trabalhista, matérias de jornais, atas de sindicato, entre outras. As análises apresentadas transitam em estudos sobre poder, cultura, memória e história, história política e do trabalho.
\end{abstract}

Palavras-chave: Trabalho operário. Produção têxtil. Resistências. Fábrica Carmen.

\section{In the weavings of industry work: textile production and uncertain life in the Carmen Factory in Fernão Velho - AL $(1940$ - 1960)}

\begin{abstract}
This article proposes to narrate the historical experience of the work in the textile industry in Fernão Velho, Alagoas. This location is part of a factory territory formed by the Carmen Factory, formerly Companhia União Mercantil, and its working village. In this narrative, textile production, worker labor, factory working conditions, class representations, and resistance movements of workers are historically recovered. As a documentary corpus, we use reports of workers registered through the oral history methodology, factory reports published in the official journal of Alagoas, photographs, labor process, newspaper articles, union minutes, among others. The analyzes presented move into studies on power, culture, memory and history, political and labor history.
\end{abstract}

Keywords: Worker work. Textile production. Resistances. Carmen Factory. 
A palavra "tecitura" na língua portuguesa designa um conjunto de fios que se entrecruzam através de um processo de urdidura. Exige-se, para tanto, a sucessão cadenciada de ações, movimentando toda uma engrenagem entre corpos e máquinas. Seu resultado é uma trama que toma forma de tecido. Partindo dessa premissa, proponho-me então a recuperar tecituras operárias, urdindo com fios de memórias, histórias e experiências no mundo fabril do ramo têxtil. Estas, como delineamento de uma trama, permitirão adentrar no cotidiano, nas rotinas e condições de trabalho no passado de uma fábrica têxtil.

Neste artigo', tomo como cenário o interior da Fábrica Carmen, localizada em Fernão Velho na cidade de Maceió, Alagoas. Trata-se da primeira fábrica têxtil nesse estado e uma das primeiras no Brasil, fundada em 1857 com o nome de Companhia União Mercantil (TAVARES, 2014) por José Antônio de Mendonça (o Barão de Jaraguá) e Tibúrcio Alves de Carvalho. Era um período de expansão da produção algodoeira no país (STEIN, 1979), e Alagoas já se tornara, à época, uma província exportadora de algodão (TAVARES, 2019).

Esta fábrica enfrentou algumas dificuldades iniciais, tendo sua produção somente iniciado em 1864 (FARIAS, 2014) em virtude da necessidade de capitalização dos seus sócios através de empréstimos. Segundo Stein (1979, p. 64), a então Companhia União Mercantil, no ano de 1866, funcionou com um total de 1.625 fusos $^{2}$ e 40 teares, empregando 8 estrangeiros e 35 trabalhadores brasileiros como operários. Superadas algumas dificuldades iniciais, como o baixo valor nominal de suas ações e um surto de malária que acometeu diversos operários, logo expandiu sua produção. Passou a fabricar diversos tipos de tecido, tais como panos para vestimentas de escravos, sacos, toalhas, lençóis, brins para calças e redes (SANT'ANA, 2011).

\footnotetext{
"Este artigo é um fragmento extraído e adaptado de minha tese de doutorado intitulada "Do tecer da memória ao tecido da história: operários, trabalho e política na indústria têxtil de Fernão Velho (1943-1961)", defendida em 2016 no Programa de Pós-Graduação em História da Universidade Federal de Pernambuco - UFPE, sob orientação do Prof. Dr. Antônio Jorge Siqueira, e que contou com financiamento de bolsa da Coordenação de Aperfeiçoamento de Pessoal de Nível Superior - CAPES. Na construção dessa narrativa, foram utilizados documentos que compõe os acervos do Arquivo Público de Alagoas - APA, Instituto Histórico e Geográfico de Alagoas - IHGAL, e Memorial Pontes de Miranda, além de entrevistas e outras fontes de acervo pessoal.

2 Trata-se de um utensílio cilíndrico feito de madeira ou metal integrante de máquinas de fiação e tecelagem na produção de fios e tecidos de algodão. Nos fusos são enroladas as linhas. Sua forma cilíndrica permite girá-lo, enrolando ou desenrolando os fios durante a produção têxtil. Quanto maior fosse a quantidade de fusos, maior era a capacidade de produção.
} 
Em Alagoas, até o final do século XIX, foram criadas mais quatro fábricas têxteis: a Companhia Pilarense de Fiação e Tecidos, Fábrica Cachoeira, Fábrica Companhia Progresso Alagoano e Companhia Industrial Penedense (MARROQUIM, 2000). No ano de 1891, José Teixeira de Machado comprou e assumiu a gestão da Companhia União Mercantil. Seus filhos, Antônio de Mello Machado e Arthur de Mello Machado, mantiveram o controle acionista com a família até o ano de 1938 (TAVARES, 2016). Nessa gestão, entre a passagem do século XIX para o XX, Fernão Velho foi gradativamente sendo delineado como território fabril composto por um sistema de fábrica com vila operária.

Para o antropólogo Sérgio Leite Lopes (1988), tratava-se de um sistema de dominação capaz de imobilizar o trabalhador, fixando-o na vila operária, resguardando seu tempo e disponibilidade para o trabalho fabril. Ou noutros termos, formava-se o que Telma de Barros Correia (1998) designou como núcleo fabril, um equipamento de arregimentação e higienização do trabalhador, permitindo controlar seu trabalho e vida social. Esse modelo de gestão do trabalho, da vida operária e da produção, direcionava mudanças na gestão do trabalho rumo a um então novo regime disciplinar cuja pretensão e idealização era fomentar "um espaço de produção tranquilo, agradável, limpo e atraente para o trabalhador e tratá-lo como um cidadão consciente e inteligente" (RAGO, 2014, p. 57).

A família Machado promoveu diversas intervenções em Fernão Velho. Edificou um depósito de algodão anexo ao edifício da sua unidade fabril. Construiu calçadas e novas casas para os operários ${ }^{3}$ que ali chegassem para viver e trabalhar. Proporcionou a oferta de cinema, colégio, igreja e ambulatório, todos mantidos pela Companhia União Mercantil. Segundo Cipriano (1999), ampliou a capacidade produtiva como um todo.

Fernão Velho passou ainda pela gestão da família Leão (1938-1943) (TAVARES, 2014), fomentando inovações técnicas na geração de energia, e na gestão (FERREIRA, 1997). Nessa época, Alagoas já contava com um total de 12

\footnotetext{
${ }^{3}$ Para maiores informações, ver: COMPANHIA UNIÃO MERCANTIL. Relatório da Companhia União Mercantil para ser apresentado à assembleia geral dos acionistas em 06 de março de 1911. In: RECORTES DO DIÁRIO OFFICIAL DO ESTADO DE ALAGOAS. Maceió: Instituto Histórico e Geográfico de Alagoas, [19--]. 1 v.
} 
Nas tecituras do trabalho operário: a produção têxtil e a vida incerta na Fábrica Carmen em Fernão Velho - AL (anos 1940 - 1960)

Marcelo Góes Tavares

fábricas têxteis, assim como mais de 79 unidades de beneficiamento de algodão espalhadas por diversos municípios do interior (TAVARES, 2019). Em 1943, a então Companhia União Mercantil foi adquirida por Othon Lynch Bezerra de Mello, integrando a Companhia de Tecido Bezerra de Mello. Somava-se ao conjunto de outras fábricas nos estados de Pernambuco, Rio de Janeiro e Minas Gerais (MELLO, 2012). Nesse ano, a unidade fabril de Fernão Velho, em Alagoas, foi rebatizada para Fábrica Carmen. Permaneceu sob a gestão de Othon, sua Companhia, e filhos, até o ano de 1996.

Nos anos 1940, a Fábrica Carmen funcionava plenamente. Nela, operários e máquinas urdiam-se em um só corpo produtivo, porém o cotidiano de suas engrenagens nem sempre era harmônico, sem que se eximissem as tensões entre humanos e máquinas, operários e fábrica. Apesar da propaganda empresarial que positivava suas próprias ações e informava uma melhor qualidade de vida aos trabalhadores quando providos por sua política de assistência patronal, para os operários se configurava uma situação de sustento de si e suas famílias. A produção fabril tornava-se um campo de lutas, seja dos patrões desejosos por maior produtividade e eficiência, seja dos operários na labuta por sua sobrevivência.

\section{A produção têxtil em Fernão Velho ${ }^{4}$}

Eram seis horas da manhã. A sirene da Fábrica Carmen tocava pela primeira vez logo após o nascer do sol. Ecoava por Fernão Velho, sendo ouvida por todos que ali viviam e trabalhavam. Esse som se repetiria mais algumas vezes ao longo do dia e da noite. Cada vez que soava, operários e operárias entravam na unidade fabril ocupando as seções para o exercício de suas funções laborais.

\footnotetext{
${ }^{4}$ Essa narrativa sobre a produção têxtil em Fernão Velho abrange o período entre os anos 1940 e 1960. Foi elaborada com base em diversos testemunhos de operários da Fábrica Carmen, registrados em entrevistas com uso da metodologia da história oral. Referenciamos essas entrevistas nas fontes documentais utilizadas para este artigo, e quando citadas, compõem este relato sobre o passado preservando seu caráter fiduciário. Foram ainda considerados, os relatórios dessa unidade fabril publicados anualmente no Diário Oficial de Alagoas, verificandose a ocorrência ou não de mudanças substanciais na infraestrutura das instalações produtivas. São plausíveis, desse modo, pequenas diferenciações entre o acontecido e o relatado nos testemunhos. Portanto, esclarecemos que se trata de uma representação verossímil, construída pelo exercício da reminiscência e imaginação, e que ganha forma de uma representação historiadora - uma representância - tomando o lugar do passado (RICOUER, 2007).
} 
Nas tecituras do trabalho operário: a produção têxtil e a vida incerta na Fábrica Carmen em Fernão Velho - AL (anos 1940 - 1960)

Marcelo Góes Tavares

Simultaneamente, outros saíam. Todos se alternavam, iam e vinham das suas casas, ou outros locais naquela vila operária. Era um tempo de produção contínua, sem cessar, com escalas de trabalho que adentravam a noite e continuavam já em um novo dia. A sirene demarcava o tempo da produção.

Findava-se um turno, iniciava-se outro, dividindo-se em escalas de quatro horas de trabalho. Às $6 \mathrm{~h}$ da manhã, entrava a primeira turma de operários, permanecendo até às 10h, quando a sirene soava pela segunda vez no dia. Indicava a transição para o segundo turno que durava até às $14 \mathrm{~h}$. O terceiro se estendia até às 18h. O quarto até às $22 \mathrm{~h}$ quando a sirene soava pela quinta vez. Era o último e diferenciado turno! Os que adentrassem na Fábrica, permaneciam até às $6 \mathrm{~h}$ da manhã. Geralmente cumpriam essa escala os operários que desejassem somar horas extras, receber por produção, ou mesmo preferiam trabalhar oito horas corridas com um breve intervalo na madrugada 5 .

Em Fernão Velho, além da sirene, os operários lembram, ao relatarem suas memórias, que se ouvia permanentemente o barulho que vinha da Fábrica Carmen e que ecoava pela vila operária6. "Passei muitos e muitos anos ouvindo a tecelagem aí na frente de casa. A zoada era grande. Pááááá, páaaa... Centenas de máquinas. Páaaaaa, paaaaa. Era aquela zoada. O dia todinho, e a noite também”, relatou Zequinha Moura (2014)7. À medida que a sirene demarcava a divisão do tempo em turnos, a "zoada" que durava dia e noite sinalizava a incessante produção8 . Esse conjunto expressava o funcionamento da engrenagem fabril.

\footnotetext{
5 Para recuperar as escalas e turnos de trabalho na Fábrica Carmen tomou-se como base os depoimentos dos operários Zequinha Moura (2014) que residia em frente à Fábrica Carmen, e de Carlos Caracciolo (2015), que exerceu funções de controle produtivo em seções dessa unidade fabril. Esses depoimentos foram registrados com base na metodologia da história oral.

${ }^{6}$ Franco (1983) analisa aspectos produtivos da indústria têxtil no Nordeste brasileiro. Oferece dados relevantes sobre as condições de funcionamento de suas fábricas, destacando inclusive, a potencialização da mais-valia e as condições dos antigos maquinários têxteis. Podemos então considerar que os barulhos e ruídos emitidos na fabricação de fios e tecidos representam também a precarização do trabalho incidindo, inclusive, nos corpos e condições de saúde dos operários.

7 Trata-se de José Acioly Neto. Enfatiza, por informação verbal, que é mais conhecido em Fernão Velho como Zequinha Moura. E assim, declara sua preferência em ser nomeado.

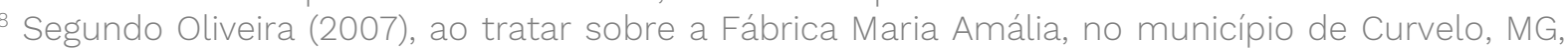
também mantida pelo Grupo Othon, relata que os níveis de ruídos não eram respeitados até 1992, quando foi implantado o setor de Segurança do Trabalho e passou-se a usar equipamentos como protetores auriculares e máscaras respiratórias. Antes disso, muitos operários dessa fábrica declararam ter alguma deficiência auditiva ou perda parcial da audição.
} 
Os operários da Fábrica eram diversos: homens, mulheres, jovens e pessoas de idade madura (MEMÓRIA...,1986). Dividiam-se em diversas funções na produção têxtil. Dona Emília (2014) destaca a partir de suas memórias, que havia tecelões, urdideiros, fiandeiros, caldeiros, cardistas, azeiteiros, pessoal do acabamento e expedição, contramestres, encarregados de setor e gerentes ${ }^{9}$. Trabalhavam diretamente na produção dos fios e tecidos. Carlos Caracciolo (2015) relatou que a denominação da função de cada operário se dava por meio da seção ou setor onde trabalhava.

O funcionamento do território fabril abrangia diferentes atividades, dentro e fora da Fábrica Carmen. Sobre essas atividades e respectivas funções, as memórias de Zequinha Moura (2014) registradas em entrevista são bastante esclarecedoras. Informa que na administração, também conhecida como "escritório", trabalhavam cerca de 30 funcionários. Entre eles, estavam os office boys, secretárias, entre outros, que não tinham necessariamente uma função nomeada, mas faziam de tudo um pouco no apoio à gestão. Havia também os motoristas, mecânicos, pedreiros, pintores, carpinteiros, lenhadores e vigias. Realizavam a manutenção da Vila Operária e da Fábrica, além de dar apoio à produção quando necessário. Mudanças de função eram algo comum, inclusive por promoção. Segundo Carlos Caracciolo (2015) e suas memórias, a fábrica empregava ainda enfermeiros, médicos, contadores e advogados, professoras e até um padre, a exemplo do Pe. Cabral que foi diretor do Colégio São José. Esses davam suporte à gestão do corpo produtivo e atuavam nos diversos serviços assistencialistas disponibilizados aos operários.

O espaço da produção era composto por diferentes seções. Havia as caldeiras, armazém de algodão e almoxarifado, a fiação, a preparação para a tecelagem, a tecelagem, o acabamento com sala de fazendas e expedição, e o escritório onde era realizada toda a administração. A Fábrica Carmen foi desmontada a partir de seu fechamento em 2010. Restam suas paredes, sem, contudo, identificar seus espaços, seções, entre outras informações que permitam melhor reconhecer e compreender ali um espaço produtivo e do 
trabalho. Exige-se recorrer ao esforço de lembrança daqueles que ali vivenciaram suas práticas do trabalho.

Carlos Caracciolo foi gerente de produção na Fábrica Carmen, onde também atuou controlando a qualidade do que era produzido. Possuía curso técnico em tecelagem realizado no Rio de Janeiro na década de 1960. Trabalhou em diversas fábricas têxteis em Pernambuco, Bahia e Alagoas. Como funcionário do grupo Othon, e sendo um operário experiente em seu labor, teve oportunidade de atuar na Fábrica Maria Amália no município de Curvelo, MG, também mantida pelos Othon. Atuando em diversas funções na Fábrica Carmen, relatou ${ }^{10} \mathrm{com}$ detalhes a disposição de cada sala e galpão no seu interior. Esclareceu que ao chegar em Fernão Velho já encontrou essa estrutura produtiva, sendo, portanto, o resultado das intervenções dos Othon e grupos gestores anteriores, naquele complexo de fábrica com vila operária. A partir de seu trânsito pelas instalações da Fábrica Carmen, pôde dispor de uma memória sobre o vivido ali. Imaginou e produziu um mapa com lugares e pontos de referência, representando a distribuição das seções e seus respectivos setores.

Imagem 1 - Fábrica Carmen: representação da distribuição de salas e setores de produção nos tempos dos Othon

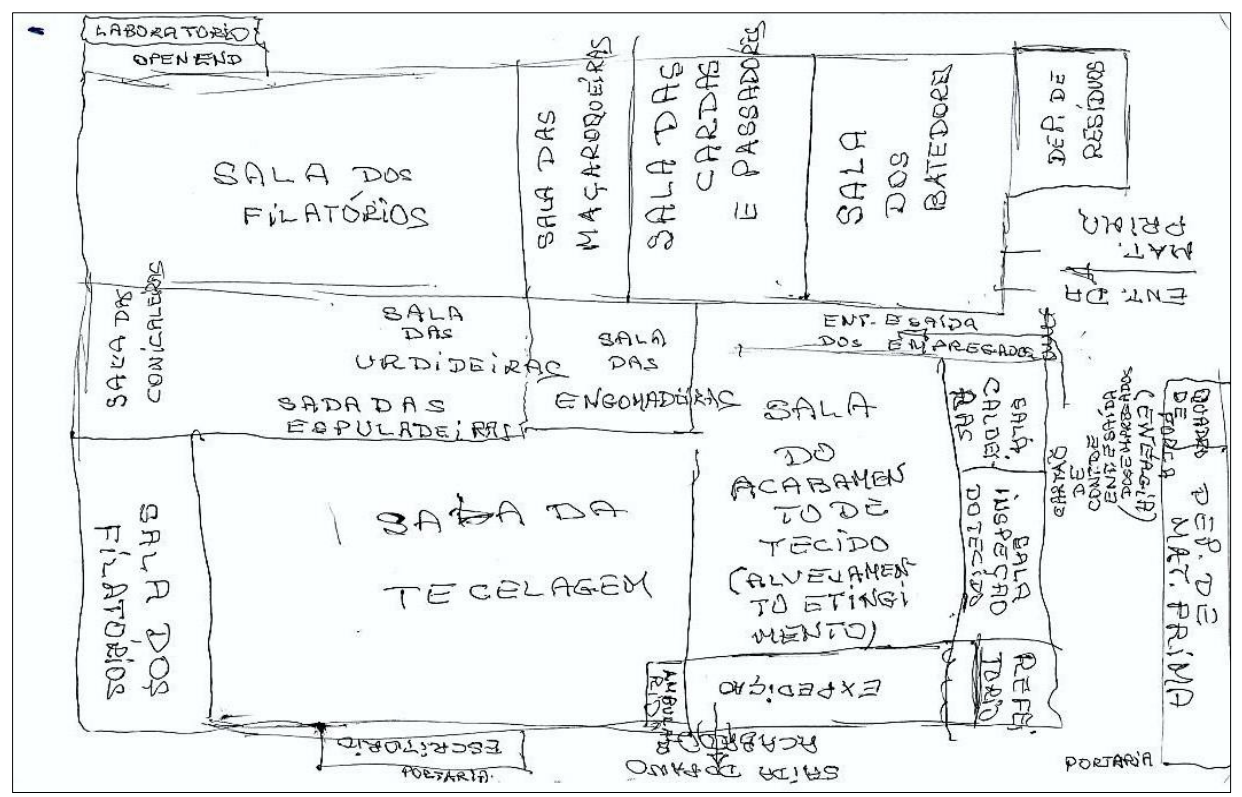

Fonte: Carlos Caracciolo, 2015. Acervo Pessoal de Marcelo Góes Tavares.

10 Relato de Carlos Caracciolo, cidade de Maceió, bairro de Fernão Velho. Entrevista cedida a Marcelo Góes Tavares em 11/07/2015. 
Nas tecituras do trabalho operário: a produção têxtil e a vida incerta na Fábrica Carmen em Fernão Velho - AL (anos 1940 - 1960)

Marcelo Góes Tavares

Além dessa representação, Carlos Caracciolo cedeu um testemunho sobre os processos fabris na Fábrica Carmen, permitindo-nos narrar (BENJAMIN, 1994a) e extrair dos conteúdos formais do passado, condições de possibilidades de um processo efetivo de operação historiográfica (RICOEUR, 2007) sobre Fernão Velho. Seu relato evidencia a estrutura física e produtiva com a disposição de algumas seções e setores dessa unidade fabril.

Imagem 2 - Fábrica Carmen após ampliação nos tempos dos Othon

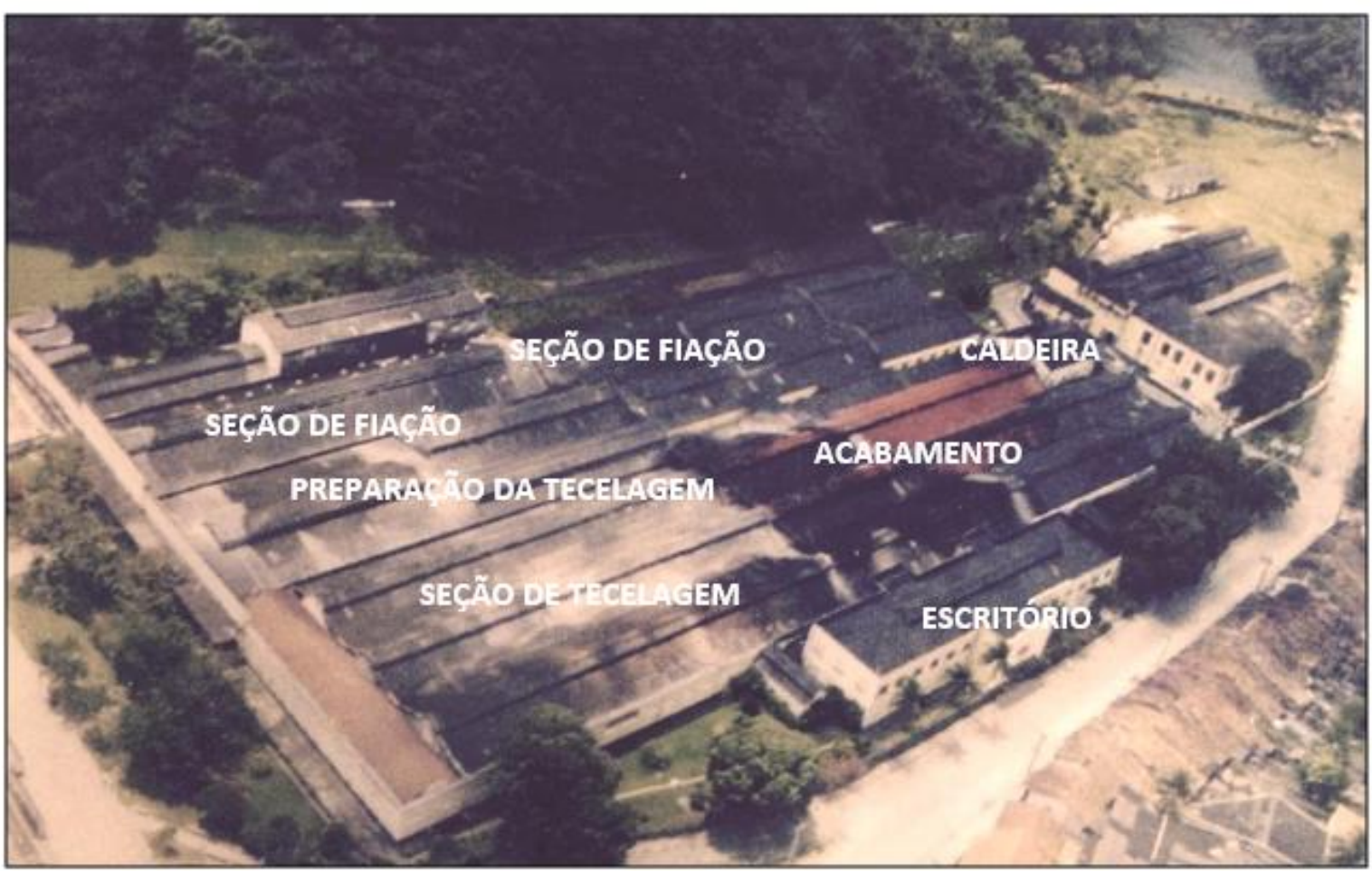

Fonte: FÁBRICA CARMEN FIAÇÃO E TECELAGEM S/A, [1997].

Prospecto de demonstração de tecidos. Acervo pessoal de Marcelo Góes Tavares.

Os relatos de Carlos Caracciolo (2015), Zequinha Moura (2014), Dona Emília de Souza (2014), entre outros trabalhadores de Fernão Velho, ao cederem suas entrevistas trouxeram à tona o que se compreende por memória subterrânea (POLLAK, 1989). Esta emerge da iminência do esquecimento, contribuindo para a afirmação de identidades e pertencimentos a um lugar, atividade, cultura, referenciais que ajudam a localizar os sujeitos e suas ações no tempo e no espaço. No exercício da reminiscência - lembrança e esquecimento - em meio à imaginação sobre o vivido por diversos operários contemporâneos dos tempos 
Nas tecituras do trabalho operário: a produção têxtil e a vida incerta na Fábrica Carmen em Fernão Velho - AL (anos 1940 - 1960)

Marcelo Góes Tavares

de funcionamento da Fábrica Carmen, possibilitou-se recuperar aspectos da produção e do trabalho fabril no ramo têxtil. Trata-se de uma memória que, para Benjamin (1994b), salta ao presente e torna plausível reconhecer uma experiência (BENJAMIN, 1994c) que podemos designar como "operária”.

A produção seguia toda uma cadência de movimentos sequenciados, todos devidamente quadriculados dentro do espaço produtivo que era organizado de forma a assegurar eficiência. Para isso, era relevante um corpo produtivo de excelência, que dominasse suas atividades e o ritmo necessário da produção em meio ao conjunto da maquinaria produtiva. Exigiam-se também conhecimentos técnicos e/ou práticos sobre os materiais, condições ambientais (níveis de umidade e temperatura) de cada seção, medidas e elasticidade dos fios, quantidade de fios necessários no urdimento e tramas de cada tipo de tecido a ser fabricado, entre tantos outros.

Imagem 3 - Produção fabril em Fernão Velho nos tempos da Fábrica Carmen: do algodão ao fio, do fio ao tecido

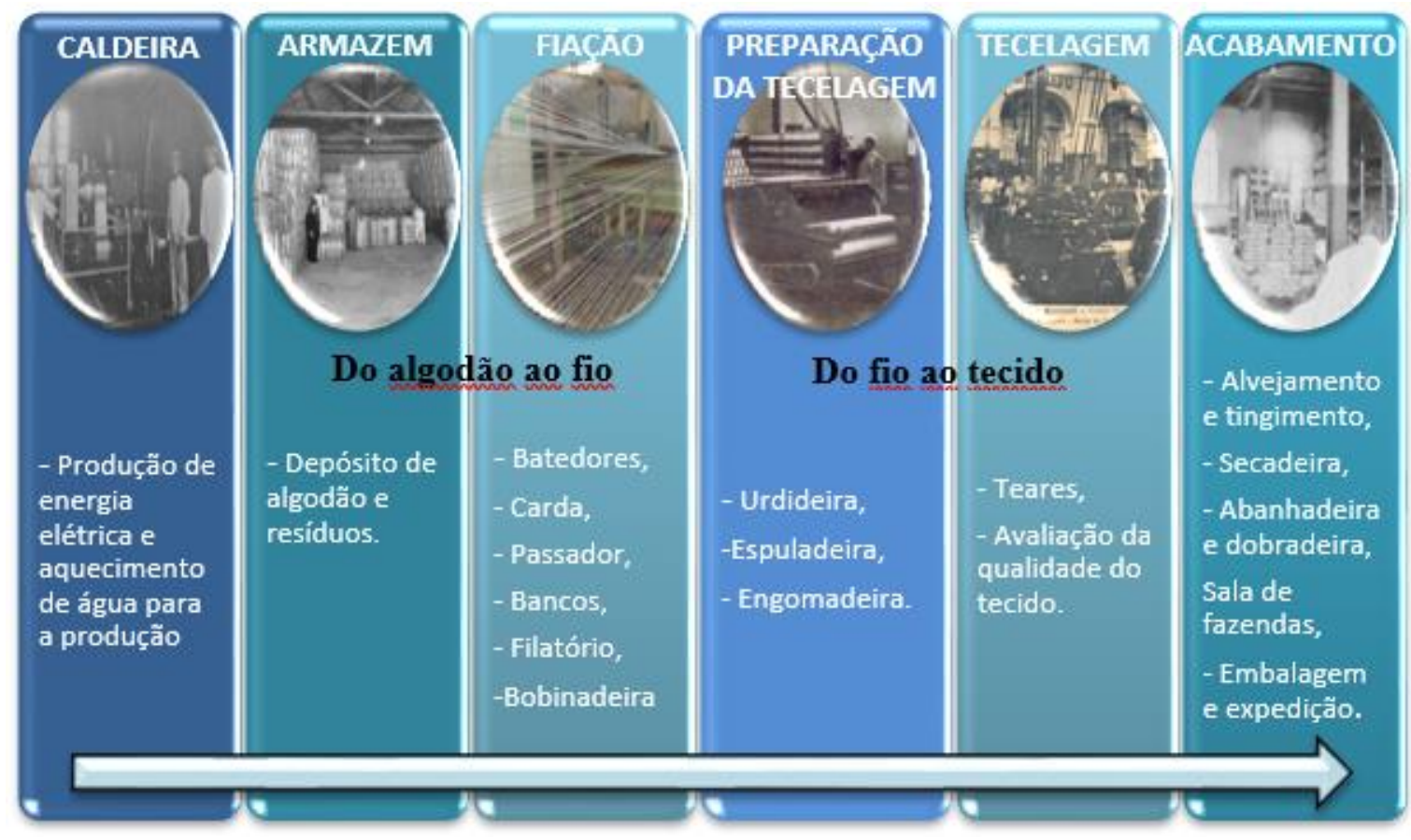

Fonte: TAVARES, 2016, p. 152.

A produção, segundo Carlos Caracciolo (2015) iniciava com a preparação da matéria-prima, o algodão. Diversos operários de Fernão Velho lembram que 
havia uma balança. Ficava na rua próxima à entrada da Fábrica Carmen. Todo carregamento de algodão, quando chegava, era levado para a pesagem nessa balança. Somente após aferido o volume e o peso da matéria-prima, é que era encaminhada para o armazém. Anterior aos anos 1960, o armazém era localizado fora da fábrica, na Rua Barão de Jaraguá, onde funciona no momento de escrita deste artigo, a Escola de Ensino Fundamental Hermínio Cardoso ${ }^{11}$. Era uma localização praticamente ao lado da estação ferroviária. Uma vez no armazém, o algodão permanecia durante o tempo necessário para que perdesse seu excesso de umidade, antes de ser utilizado na produção dos fios.

Enquanto isso, as caldeiras funcionavam com toda força na geração da energia elétrica utilizada na Vila Operária, e, sobretudo, na Fábrica. Aquecia também a água necessária em diversas atividades da produção, tais como, lavagem do algodão, engomação e desengomagem dos fios, tingimento e alvejamento dos tecidos.

A fabricação propriamente dita, segundo Zequinha Moura (2014), iniciava na seção de fiação. Compreendia seis processos: os batedores, a carda, o passador, os bancos, o filatório e a bobinadeira. Primeiramente, o algodão chegava ao setor dos batedores. Eram fardos e mais fardos de algodão para um primeiro tratamento. Eles eram abertos, limpos e transformados em flocos. Posteriormente, eram encaminhados para o setor da Carda. Nesse setor, os operários eram chamados de cardistas. Manipulavam o algodão colocando-o em uma máquina que o transformava em mantas, facilitando a retirada de detritos como caroços, palha, insetos entre outros possíveis que tivessem restado. Uma vez realizado esse processamento e limpeza, as mantas então eram transformadas em cordas quando submetidas às máquinas passadoras.

As cordas caíam em grandes baldes que eram preenchidos até a borda, e saíam deles passando pelos bancos e filatórios para reduzir suas espessuras e volumes. Nos passadores, as cordas eram submetidas a um grande cilindro, uniformizando suas fibras em peso e comprimento, sendo enroladas em bobinas onde já se aproximavam a uma espessura de cordões, quase se tornando fios.

\footnotetext{
${ }^{11}$ Hermínio Cardoso foi presidente do sindicato têxtil de Fernão Velho entre 1969 e 1972.
} 
Os operários fiandeiros e cardistas então encaminhavam as bobinas para a seção seguinte.

Na preparação para a tecelagem, a temperatura ambiente dessa seção oscilava entre 60 e 80 graus centígrados. Os "quase fios" saíam das bobinas e passavam pelas máquinas urdideiras, sendo torcidos, esticados e afinados, transformando-se em fios que rompiam com frequência e facilidade. Precisavam ser novamente unidos, sendo necessárias as mãos ágeis e delicadas de operárias, chamadas nesse setor de urdideiras. Cabia a elas uni-los novamente, fazendo emendas, como relatou Dona Emília (2014) ao lembrar seu trabalho nessa seção de preparação da tecelagem.

Os fios eram manipulados de modo a se manterem unidos, encaminhando-os para serem enrolados em tubos menores, muito embora ainda não estivessem prontos para serem utilizados na tecelagem. Não tinham a resistência e elasticidade necessárias para aguentar a força das próximas máquinas, assim como também apresentavam pequenas pelugens de algodão que soltavam, podendo impedir sua passagem por pequenos orifícios na tecelagem. Para adquirir melhor homogeneidade, menor espessura e maior resistência e flexibilidade, quando saíam das urdireiras seguiam para grandes rolos que os submetiam a um processo de engomação.

Sobre esse processo, o operário Zequinha Moura (2014) assim lembrou:

Os rolos iam para o setor de engomadeira. Eles botavam os rolos lá e a goma ia descendo a linha para poder ficar no tanque cheio de goma. Ali o fio saía engomado. Dali o fio já saía engomado e ia justamente para a tecelagem.

A goma para aplicação nos rolos de fios era preparada a partir de substâncias naturais como massa da mandioca, milho, entre outras. Eram ainda acrescidos componentes químicos que facilitavam sua fixação. Era um setor muito quente. Os fios, durante a engomação, eram aquecidos, esticados e novamente enrolados em outros tubos, formando rolos menores nas máquinas liçadoras que os separavam por meio de pentes liços. Estes alimentavam cones menores denominados espulas. Nessa etapa, pode-se afirmar que o fio já fora transformado em linha. A linha, ao ser engomada, reduzia seu atrito com a 
máquina acelerando seu deslizamento na produção do tecido, e ao mesmo tempo, evitando seu rompimento.

Era um processo que exigia destreza e rapidez, como relata Zequinha Moura (2014):

Vinham os rolos de fio, de linha, e era para passar por dentro de uma lamelazinha para a máquina. Botava a linha aqui e puxava. Era muito rápido. Colocava na lamelazinha e passava para a máquina. Os fios ficavam naquela lamelazinha e ia enrolando. Essa função era no setor de tecelagem.

Carlos Caracciolo (2015) lembrou que os gerentes de produção nessa seção julgavam que as mãos femininas eram mais adequadas em razão da suposta delicadeza para a manipulação das máquinas espuladeiras. Fato esse que coadunava com a idealização presente nas conclusões de um "inquérito científico" sobre o trabalho feminino realizado ainda em 1931 por Clodoveu Doliveira, funcionário do Departamento Nacional do Trabalho à época ${ }^{12}$. Ele afirmava que o trabalho feminino seria mais conveniente para a produção. As mulheres, segundo o inquérito, não teriam aspirações financeiras e também não faziam uso de vícios como o fumo. Desse modo, seria mais pedagógico o zelo da moral e do trabalho. Produzia um mito de eficiência para essa força de trabalho que era pautado na repetição de tarefas e movimentos, cumprimento de horários, responsabilidade pelo seu labor e por suas atividades domésticas. Trata-se de uma idealização que expressava o caráter machista e patriarcal do trabalho fabril, mesmo quando havia expressiva presença feminina. Eram trabalhadoras submetidas à subserviência em um ambiente predominantemente gerido por homens, seja na direção da fábrica, seja nas suas seções com os gerentes e contramestres.

Com o Grupo Othon (1943-1996) em Fernão Velho, a preocupação com esse modelo de gestão dos operários na produção também fora registrada em suas outras fábricas têxteis ${ }^{13}$, talvez se aproveitando das mãos femininas,

\footnotetext{
${ }^{12}$ Esse estudo se constitui como fonte e está disponível em PINHEIRO, Paulo Sérgio; HALL, Michael M. A classe operária no Brasil: condições de vida e de trabalho, relações com os empresários e o Estado: documentos. São Paulo: Brasiliense, 1981.

${ }^{13}$ O sociólogo Gladson M. de Oliveira (2007, p. 77) destaca que essa situação também ocorreu em Curvelo, MG, na Fábrica Maria Amália. A maior parte dos trabalhadores nas seções de fiação e tecelagem era composta por mulheres.
} 
acreditando que fossem mais adequadas e sensíveis para manipulação dos fios. As próprias mulheres, predominantes nos diversos setores e seções, exceto nas atividades que exigiam maior força física como os mecânicos, azeiteiros, caldeireiros, armazém e setor de acabamento, eram passíveis de serem exemplos de boas operárias para os demais.

Dona Emília de Souza (2014) lembrou com orgulho que seu retrato era exposto na Fábrica da Macaxeira pertencente aos Othon em Recife. Embora nunca tenha ido a essa fábrica, assegurou que sua informação era verdadeira, pois tomou conhecimento de sua exposição pelo próprio Alberto, um dos proprietários e filho de Othon Bezerra de Melo. Ela era considerada uma das melhores urdideiras, ao ponto de ser conhecida por todos, dos contramestres e chefes até os proprietários da Fábrica Carmen. Destacou que sempre recebia prêmio por produção. Ganhou fogão, retalhos de tecidos, entre outros. Demonstrou alegremente ter sido reconhecida como boa operária, o que a entusiasmava ao rememorar seu passado como trabalhadora. Contudo, um sentimento ambíguo, dado que sua alegria pode ser também compreendida como positivação e sujeição aos interesses da gestão fabril. Os patrões, ao primar pela eficiência e disciplina, utilizavam prêmios como forma de incentivar a produtividade.

Após o setor das urdideiras, a produção seguia pelas espuladeiras, onde era formatado o tipo de tecido a ser produzido na tecelagem. Cada tipo de tecido tinha certa quantidade de linhas a serem submetidas ao processo de urdidura e trama na tecelagem, onde ocorria o processo de fabricação do tecido. Nessa seção, a temperatura ambiente era mais baixa, oscilando em torno de 20 a 30 graus centígrados. Trabalhavam os contramestres de tecelagem, ajudantes de contramestres, ajudantes de tecelagem, os tecelões, puxadores dos rolos, azeiteiros, mecânicos e liçadeiros.

Desde os tempos anteriores à gestão da família Othon, a preocupação com a produtividade e a disciplina em Fernão Velho incidia até na disposição dos equipamentos e operários nas suas seções, quadriculando o espaço da produção. 
Imagem 4 - Operários na seção de tecelagem em Fernão Velho

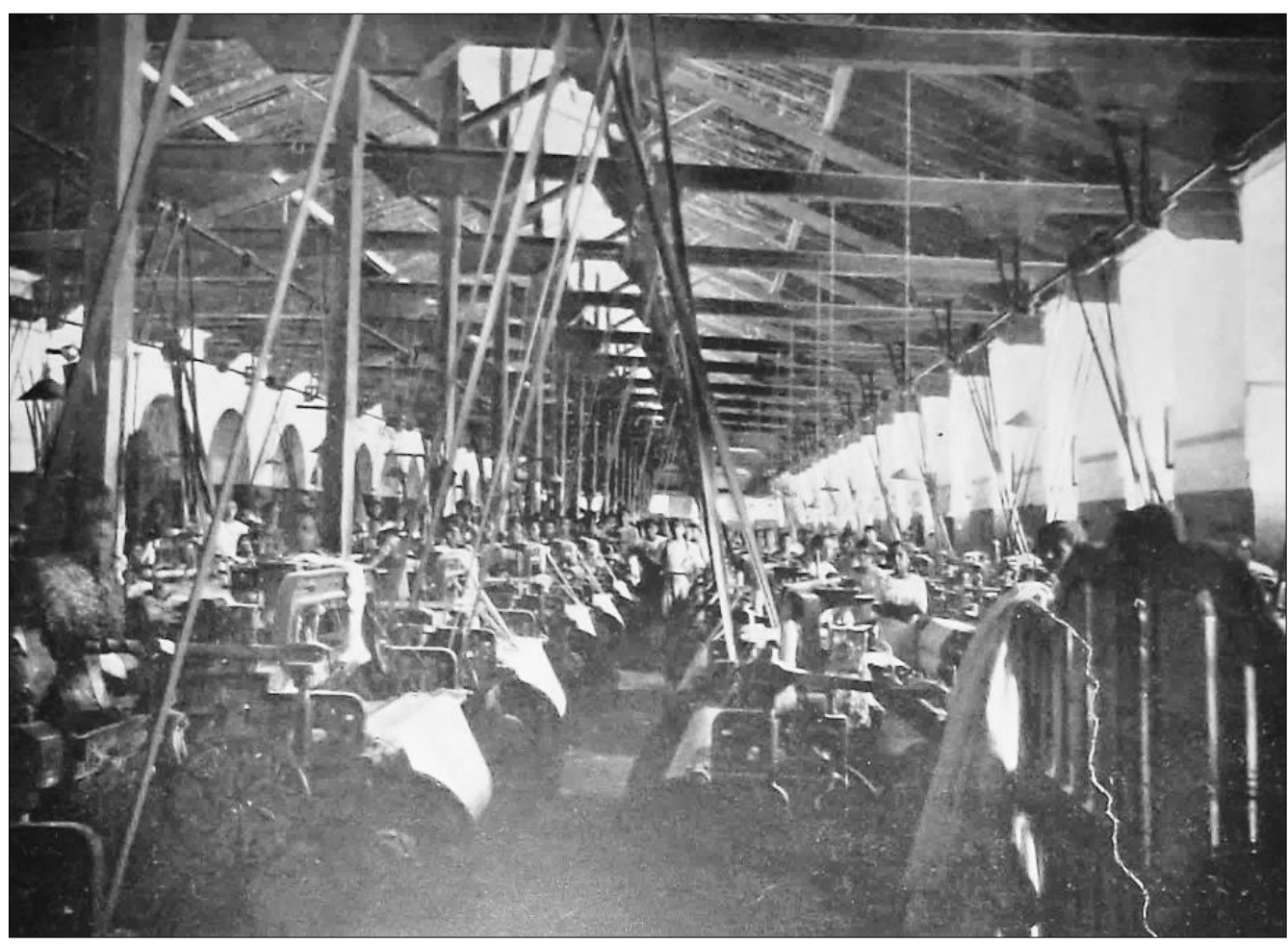

Fonte: MARROQUIM, 2000.

Era definido o lugar que cada um deveria ocupar para realizar sua função. $\mathrm{Na}$ tecelagem, as máquinas eram dispostas de forma perfilada, distribuindo equilibradamente a energia e os fios que as alimentavam. Esse "quadriculamento" possibilitava a circulação de operários entre um tear e outro, sobretudo, dos gerentes e contramestres que fiscalizavam e controlavam o ritmo do trabalho. Empregava-se, portanto, uma gestão racionalizada do trabalho e produção. E, desse modo, conforme destacaram os próprios empresários em um de seus relatórios, "A moderna instalação e a organização em série das machinas facilitando consideravelmente a fiscalização, foram as causas da referida eficiência" (COMPANHIA UNIÃO MERCANTIL, 1931, p. 5).

Os teares eram abastecidos por cones de linhas posicionadas nos seus fusos. Quanto mais fusos, mais rápida e produtiva seria a fabricação dos tecidos. Os cones eram distribuídos de cima para baixo ao longo de toda a seção realizando o urdimento das linhas. Os tecelões e as tecelãs as puxavam paralelamente e as dispunham em direção vertical a sua frente no tear, formando a urdidura do tecido. 
Na direção contrária, percorrendo de forma horizontal a máquina, passava as lançadeiras, também conhecida como porta-tramas. Era um artefato de ferro ou madeira com suas pontas de metal. Media de 25 a $40 \mathrm{~cm}$, podendo seu diâmetro variar em torno de $7 \mathrm{~cm}$. Poderia pesar até $1 \mathrm{~kg}$ a depender do material. Tinha uma cavidade no meio, de tamanho suficiente para o encaixe da espula, que era um pequeno cone com linha.

Imagem 5 - Representação das lançadeiras e seu movimento de entrelaçamento (urdimento e trama) de fios para produção do tecido

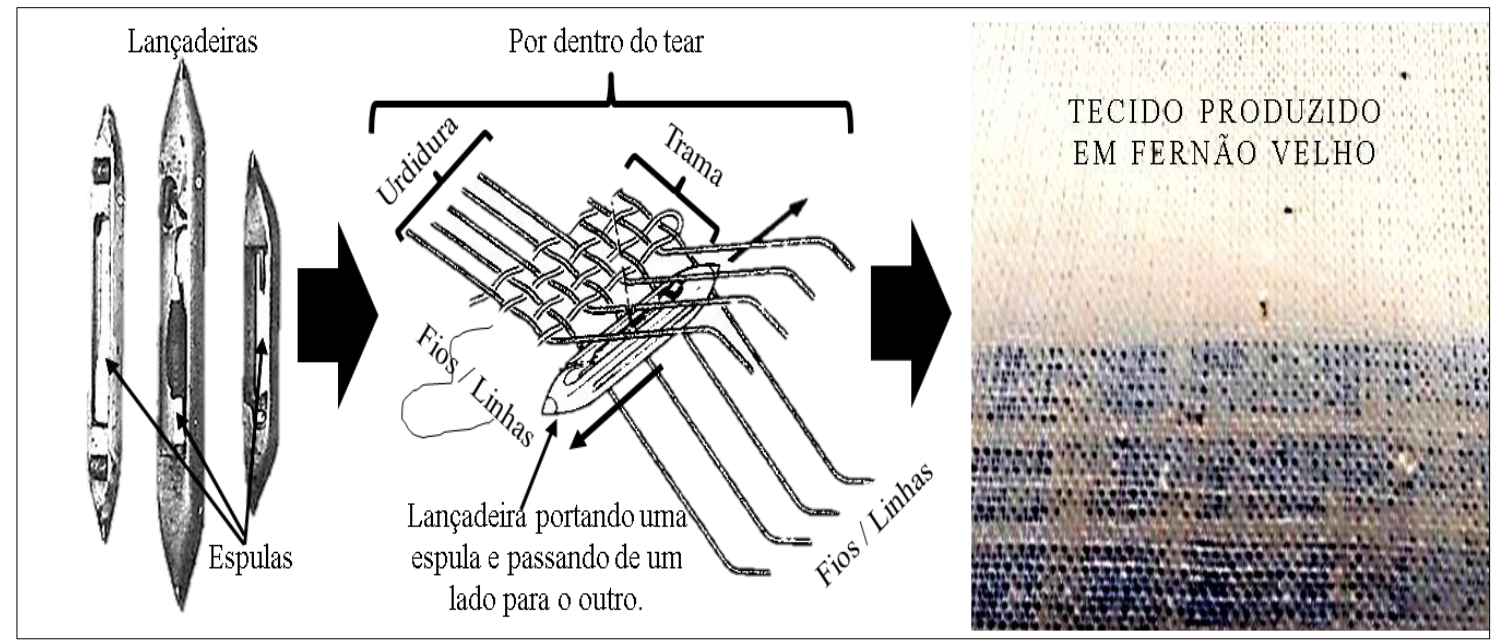

Fonte: TAVARES, 2016, p. 157.

A lançadeira operava dentro do tear contra a urdidura, realizando a trama. Passavam de um lado para outro, cruzando por cima e por baixo entre as linhas verticais em urdimento. Simultaneamente, nas frações de segundo em que a lançadeira percorria todo o urdimento, um grande pente do tear empurrava os fios em urdidura e trama, aproximando-os, dando a forma de tecido. Na tecelagem, cada tecido era produzido nos movimentos das urdiduras e tramas, entrelaçando as linhas nos teares.

Enquanto isso, um operário transitava na seção com um carrinho cheio de espulas para abastecer os teares, evitando desperdício de tempo quando um tecelão precisava abastecer o tear com linhas. Essa foi a primeira função laboral de Zequinha Moura quando iniciou suas atividades como operário, ainda adolescente. Quando acabava o fio, o tecelão trocava a espula vazia dentro da 
lançadeira por outra cheia. Puxava o fio com as pontas dos dedos, passando-a pelo orifício da lançadeira. E então a emendava delicadamente na linha anterior, o que exigia sensibilidade e destreza nas mãos.

Em Fernão Velho se produziam diversos tipos de tecidos: Fac, Lev, Carmonix, Cotton, Blanc, Bramantes, Tex e Brim. As larguras disponíveis eram de 1,43m, 1,60m, 1,65m, 1,70m, 1,80m e 1,85m. Inclusive esses produtos e respectivas informações compunham encartes de propagandas da Fábrica Carmen ${ }^{14}$. Saíam em rolos cuja largura variava de acordo com o tipo de tecido e pedido do cliente. Uma vez que o tecido estava pronto, era submetido para inspeção. Verificava-se se atendia às exigências de qualidade dos gestores e compradores. Posteriormente, eram levados para a seção de acabamento. "Acabamento era onde eles tingiam o pano. Fazia pano de xadrez, dava cor ao pano" (Relato de Zequinha Moura, 2014).

Nessa seção, os tecidos que chegavam crus podiam ser alvejados ou coloridos. Utilizavam-se produtos químicos, como cloro e tintas, o que exigia o pagamento de taxa de insalubridade para os operários que nela atuavam. Além dos tons crus, branco e xadrez, a fábrica oferecia uma variedade de cores aos clientes: tons de azul, rosa, salmão, verde e preto ${ }^{15}$. Eram ainda submetidos às máquinas de secagem, abanhadeira para fazer o alinhavado do acabamento lateral e dobradeira para dobrar os tecidos quando não eram vendidos em rolos. "Quando passava pelo acabamento, o pano já saía prontinho para ir para a sala de fazendas. Nesta, empacotava e fazia os rolos de tecido, já tudo pronto para ir para a loja, sala de fazendas." (Relato de Zequinha Moura, 2014).

A sala de fazendas consistia em um dos setores da expedição. Nela, operavam também as encartadeiras, produzindo encartes e prospectos com amostras de tecidos para os clientes. Saindo da sala das fazendas, os tecidos da Fábrica Carmen enchiam caminhões rumo ao abastecimento de mercados no Brasil e no mundo, deixando em Fernão Velho as marcas de seu processo produtivo.

\footnotetext{
${ }^{14}$ FÁBRICA CARMEN FIAÇÃO E TECELAGEM S/A. Prospecto de demonstração de tecidos.

15 Informação com base em: FÁBRICA CARMEN FIAÇÃO E TECELAGEM S/A. Prospecto de demonstração de tecidos.
} 


\section{O trabalho e os fios de uma "vida incerta" na fábrica}

O romancista Ítalo Calvino (1991), em Cidades invisíveis, narra a cidade de Otávia, uma "cidade-teia-de-aranha" localizada em meio a um precipício entre duas montanhas. Seus moradores caminhavam por trilhos de madeira pendurados, sempre olhando para a profundidade do desfiladeiro abaixo deles. Aliás, no seu dia-a-dia, toda a cidade era vivida de forma suspensa e cuidadosa, com redes, teleféricos, cordas, varais, trapézios, pendentes, tudo que exige o malabarismo e trampolinagem de seus viventes. Um cotidiano em que a morte e o perigo estavam sempre próximos, espreitando a vida dada como incerta. Reservadas as devidas diferenças, em Fernão Velho o trabalho no rés do chão da Fábrica Carmen também configurava diversas situações de incertezas da vida diante dos perigos do trabalho e ambientes laborais insalubres.

Zequinha Moura (2014) lembrava que "todos os setores, em geral, eram quentes. As pessoas acostumavam." O acostumar-se com a insalubridade do ambiente fabril não eximia os operários da situação de periculosidade nos ambientes laborais.

Em seções como a fiação e a tecelagem, muitos pêlos, fios e filamentos de algodão se desgarravam das máquinas. Eram leves o suficiente para ficarem suspensos como uma névoa no ar, podendo ser inalados pelos operários. Nas primeiras décadas do século XX, ambientes como esse favoreciam a incidência de diversas doenças respiratórias, inclusive tuberculose. Durante uma reunião do Sindicato no dia 02 de dezembro $1953^{16}$, a tuberculose se tornou um dos temas de discussão. Ressaltou-se que a doença chegava a atingir óbitos na ordem de 30\% daqueles que por ela eram acometidos em Alagoas. Um número expressivo, sobretudo tendo em vista que a eficiência do tratamento depende de boa alimentação, rigorosa higiene, repouso e ambiente salubre com boa qualidade do ar. Condições difíceis para um operário, diante do seu cotidiano no trabalho, se porventura portasse a bactéria do bacilo de Koch, causador da doença.

Segundo Carlos Caracciolo (2015), na gestão dos Othon foram instalados grandes aspersores, ventiladores que borrifavam água, e ao girar, ventilando o

\footnotetext{
${ }^{16}$ Para maiores informações, ver: SINDICATO DOS TRABALHADORES NA INDÚSTRIA DE FIAÇÃO E TECELAGEM DE FERNÃO VELHO. Ata da sessão ordinária de 02 de dezembro de 1953. In: LIVRO DE ATAS. Maceió: [o Sindicato], 1953-1964.
} 
ambiente, também pulverizavam as gotículas d’água. Formava-se uma "fumaça úmida" que tomava conta desses ambientes. Com isso, os resíduos de linhas e algodão misturados ao ar ficavam molhados e caíam no chão. Do contrário, os operários, caso os inalassem, poderiam incorrer em enfermidade por doenças respiratórias, o que traria prejuízos para a produção diante de possíveis e duradouros afastamentos. Essa preocupação da Fábrica Carmen com a saúde dos operários representava uma estratégia empresarial de manutenção do corpo produtivo. Além do que, segundo ressaltou Carlos Caracciolo (2015), na tecelagem era necessário um ambiente com 80\% de umidade relativa do ar. Era a condição ideal para a produção nessa seção.

Em meio às máquinas, os riscos no exercício do trabalho iminentes. Os acidentes de trabalho ocorriam nas diferentes seções e seus setores, mutilando, machucando, incapacitando momentânea ou permanentemente o operário. A tecelagem era uma seção com maiores ocorrências de acidentes de trabalho. Era comum as lançadeiras, mesmo com seu peso e tamanho, saltarem para fora dos teares quando esvaziavam a espula. Quando isso ocorria, seguia uma trajetória indefinida, percorrendo todo o salão da seção. Atingia quem estivesse à sua frente. Quando acertava diretamente a parede, provocava perfurações no reboco que a revestia. As paredes eram marcadas pelas lançadeiras, o que lembrava permanentemente os operários sobre os perigos que corriam quando trabalhavam naquela seção. Carlos Caracciolo (2015) relatou que era difícil encontrar algum operário tecelão que nunca fora atingido por lançadeiras.

Valdigleide (2014), que nasceu em Fernão Velho e foi operária na Fábrica Carmen até 1996, relatou que, quando trabalhava na tecelagem, uma lançadeira atingiu seu pé. Ainda possui no corpo, e na memória, a cicatriz provocada por esse acidente. Em casos mais graves, poderia atingir o rosto, o olho, provocando cegueira, ou as mãos podendo causar mutilação dos dedos. Com certa dose de cuidado e sorte, além da destreza para desviar das lançadeiras voadoras, poderse-ia evitar acidentes mais graves. A própria Fábrica Carmen já teria reconhecido em alguns episódios a periculosidade do trabalho em suas instalações.

Em 1940, publicou no Diário Oficial de Alagoasi7, uma convocação de funcionária afastada por acidente de trabalho, que teria abandonado o

\footnotetext{
${ }^{17}$ COMPANHIA UNIÃO MERCANTIL. Edital. Diário Oficial de Alagoas, Maceió, 27 mar. 1940, p. 10.
} 
tratamento ao qual estava submetida. Ou, ainda, podemos citar os registros da Companhia Alagoana de Fiação e Tecidos, que publicou em seu relatório, em 1948, a ocorrência de 599 acidentes de trabalho em suas instalações no ano de 194718. Dado esse que expressa certa realidade no cotidiano da produção industrial têxtil em Alagoas.

Nos casos de acidentes, os operários em Fernão Velho logo chamavam o contramestre ou o gerente avisando sobre o ocorrido. Mobilizava-se o atendimento ao ferido, encaminhando-o para o ambulatório onde recebia os primeiros socorros. Geralmente um curativo, ataduras ou um remédio quando se tratava de acidente menor.

Carlos Caracciolo (2015) lembrou-se de um acidente de que ouviu falar. Ocorreu na seção de acabamento durante o processo de alvejamento dos tecidos. Trata-se daquilo que Pollak (1989, p. 201) designa como "acontecimento vivido por tabela” através do grupo social ao qual o narrador se sentia pertencer. Nesse caso, um infortúnio cujas proporções possivelmente eram contadas como lembrete, ou trauma, sobre os riscos do trabalho. O cloro utilizado para alvejamento dos tecidos evaporou rapidamente com a elevada temperatura do ambiente, formando uma névoa tóxica inalada pelos operários. Provocou também queimaduras na pele e nas vias respiratórias dos operários dessa seção. Muitos tiveram de ser socorridos em prontos-socorros de Maceió em face das limitações do ambulatório da Vila Operária para demandas mais complexas de se tratar.

Embora a Fábrica contratasse médicos, dentistas e enfermeiros para seu ambulatório em Fernão Velho, diversas memórias apontam para a ausência da permanência de médicos de plantão. Aparentemente, eles atendiam apenas em alguns dias e horários predefinidos, com atendimento básico-ambulatorial. Não havia estrutura para emergência médica. No máximo alguns atendimentos de urgência, que caso não resolvessem a situação, funcionariam como paliativos até um atendimento mais adequado. A presença mais predominante de profissional de saúde era a de enfermeiras, mas que nem sempre conseguia cobrir todos os

18 COMPANHIA ALAGOANA DE FIAÇÃO E TECIDOS. Relatório da Diretoria a ser apresentado a Assembléia Geral Ordinária de Acionistas, convocada para 31 de março de 1948. Diário Official de Alagoas, Maceió, 30 mar. 1948, p. 3-5. 
horários e demandas, sobretudo quando se tratava de infortúnios mais graves. Ou, ainda, suscitavam dúvidas sobre a qualificação de alguns profissionais não médicos que trabalhavam no ambulatório. Era comum a contratação de "práticos", aquele profissional sem formação especializada e técnica, mas que pela prática exercia funções específicas e limitadas. Podemos citar como exemplo a contratação de parteiras e auxiliares que atuavam na enfermaria.

José Aquino Correia foi um desses profissionais práticos. Contra ele, a Fábrica Carmen moveu a reclamação n. 3/57 na Justiça do Trabalho, solicitando sua demissão por justa causa. O operário foi contratado como tecelão em 12 de novembro de 1941, e já tinha adquirido o direito à estabilidade por ter mais de dez anos de serviços ininterruptos naquela empresa. A fábrica o acusava de roubo por ter aberto o armário do ambulatório sem autorização, retirando medicamentos em uma madrugada. O trabalhador foi afastado da função em 3 de dezembro de 1956, embora o processo contra ele só tenha sido encaminhado à JCJ em 2 de janeiro de 1957. Foi anexada sua ficha funcional, informando licenças médicas e receitas de medicamentos que utilizou. A fábrica realizava um controle de saúde sobre seus funcionários, o que não significava que os conhecesse plenamente.

No transcorrer do processo, ficou evidente que José Aquino Correia era usuário permanente de medicamentos. Enquanto a fábrica o acusava de roubo criminalizando previamente, o advogado de defesa afirmava que ele se encontrava em tratamento médico e necessitava do medicamento. Além disso, alegou que somente retirou os medicamentos porque a enfermeira plantonista estava ausente. Também ele próprio, funcionário desse setor, tinha sido “promovido" a enfermeiro prático. Na ausência de um médico ou enfermeira de plantão, abriu o armário e fez uso do medicamento. Os gerentes da fábrica alegavam que o medicamento era apenas para uso emergencial, muito embora "aquele" que detivesse o saber técnico capaz de julgar "quanto seria emergencial naquele momento" não estivesse presente e disponível aos operários na madrugada.

O processo contra José Aquino Correia é indiciário das condições limitadas e precárias na oferta dos serviços de saúde da Fábrica Carmen para seus 
operários. Inclusive, o próprio Sindicato dos Trabalhadores na Indústria de Fiação e Tecelagem de Fernão Velho já se dispunha a custear certos serviços de saúde para seus associados, nesse caso, manter um gabinete odontológico ${ }^{19}$. Já em acidentes graves, o operário era encaminhado para algum dos hospitais de Maceió, a exemplo do caso do cloro no setor de alvejamento.

Em Fernão Velho, os acidentes não paralisavam a produção, exceto quando alguma máquina era danificada ou a seção e o setor comprometiam a segurança de todos. Embora o trabalho fabril possibilitasse o salário, a moradia, a escolarização primária das crianças, a diversão e a sobrevivência básica, mesmo assim, mantinha a vida dos operários como incerta dentro do ambiente fabril. A adaptação dos operários à rotina, aos procedimentos do trabalho, à manipulação das máquinas não conseguia evitar totalmente os acidentes ou o desgaste do corpo. Os movimentos constantes, intensos e padronizados também provocavam lesões.

Em fevereiro de 1963, João Verçosa de Aguiar já trabalhava na Fábrica Carmen, porém, somente tinha sido fichado havia cinco meses. No terceiro mês, como operário fichado e gozando dos direitos trabalhistas, foi chamado ao escritório para assinar sua demissão. O operário se negou, pois se encontrava enfermo. Dizia ter sido acometido por uma doença no trabalho. Diante da doença e do risco de perder o emprego, e tudo o mais que ele the oferecia, como a moradia de sua família, recorreu à mediação de seu sindicato ${ }^{20}$.

Tratava-se de uma situação que poderia acometer qualquer operário. Acidentes ocorriam com certa frequência nas diferentes seções e setores, de forma direta ou indireta, ou mesmo fora da Fábrica, nas atividades que davam suporte à produção. Entre estas, citamos a atividade de extração de madeira das matas que integravam esse território fabril.

Então tinha a caldeira com uma turbina que consumia 10 toneladas de lenha por dia. Eram 10 caminhões todo dia para a caldeira. E mesmo que não consumia, tinha que manter aquele

\footnotetext{
${ }^{19}$ SINDICATO DOS TRABALHADORES NA INDÚSTRIA DE FIAÇÃO E TECELAGEM DE FERNÃO VELHO. Ata de sessão ordinária de 22 de abril de 1953. In: Livro de atas. Maceió, 1953-1964.

${ }^{20}$ Esse caso é relatado na documentação sindical de Fernão Velho, em especial: SINDICATO DOS TRABALHADORES NA INDÚSTRIA DE FIAÇÃO E TECELAGEM DE FERNÃO VELHO. Ata de sessão ordinária de 17 de fevereiro de 1963. In: Livro de atas. Maceió, 1953-1964.
} 
quadrado de lenha. Não tinha como chegar da rua o caminhão sem madeira. A madeira era do Grupo Othon, era tirada do Pilar; Matriz, pra cá, tudo era propriedade da Fábrica. A Fábrica tinha machadeiro, e eu era encarregado de pegar lenha. Só para a caldeira era 10 toneladas, era 10 caminhões. (Relato de Antônio Cardoso, 2015)

As madeiras eram usadas nas fornalhas que aqueciam as caldeiras, entre outros usos. O funcionamento da fábrica gerava um expressivo impacto ambiental nas matas da região. No entanto, era com os acidentes de trabalho que a produção ganhava maior expressividade trágica. Dona Aidée, ${ }^{21}$ operária na Fábrica Carmen, lembrou suas histórias de família durante os tempos da Companhia União Mercantil. Era novembro, feriado do Dia de Finados. Sua mãe, então no oitavo mês de gravidez, foi surpreendida por um senhor que chegou à sua porta: "Ó de casa!" Quando ela saiu e ele a viu com o barrigão, ficou receoso de dizer o que se passava. Ficou momentaneamente preso no silêncio, possivelmente consternado com aquela situação. Levava uma notícia urgente: "Senhora, não tome susto não, mas seu marido está quase morto na farmácia."22

O pai de Dona Aidée era um jovem forte e exercia atividade de machadeiro. Saiu cedo para trabalhar quando sofreu um grave acidente. "Caiu um pau na cabeça dele que enterrou o pescoço e foi dois homens ou três para segurar o corpo e o outro para deslocar a cabeça do pescoço, puxar a cabeça dele." (DONA AIDÉE, 2008). Sua mãe, então grávida e desesperada com o que se sucedia, seguiu ao encontro do seu marido, cuja vida se esvaía. Chegando à farmácia, viu o marido com sangue que saía por quase todos os orifícios do corpo. Nariz, boca, ouvido... Era muito sangue. O jovem cortador de lenha faleceu sufocado de sangue quando trabalhava para a fábrica e sustento de sua família.

Então a minha mãe quase que perdia a visão da vista de tanto chorar só de pensar como ia criar agente, e eu ia nascer sem ninguém em casa trabalhar. Nesse tempo não existia ainda INPS. ${ }^{23}$ e nem esse negócio da pessoa trabalhar, tá doente vai pra casa que tem direito, não existia licença. (DONA AIDÉE, 2008)

\footnotetext{
${ }^{21}$ Esse relato se encontra disponível para consulta no Arquivo Público de Alagoas (APA).

${ }^{22}$ A farmácia localizava-se no Ambulatório da Fábrica. Muitos operários designavam esse lugar como farmácia, embora outros serviços médicos fossem lá ofertados.

${ }^{23}$ Trata-se do Instituto Nacional de Previdência Social (INPS), responsável pelo recolhimento do pagamento da contribuição do trabalhador para efeitos de aposentadoria. Com a ampliação dos direitos de benefícios previdenciários na Constituição de 1988, o sistema previdenciário brasileiro passou por reformas. Em 1989, o INPS foi extinto, passando suas atribuições para o Instituto Nacional de Seguridade Social (INSS).
} 
Nesse desamparo, a família passou a contar com o suporte material e financeiro dos Machado, então proprietários da fábrica, que, diante da morte trágica de um funcionário no exercício de seu trabalho, tentavam de alguma forma compensar a perda daquela família. Passaram a doar alimentos, como se fosse uma cesta básica, além do que mais precisassem para as crianças pequenas, filhos da viúva. Doaram também o enxoval de bebê da então recémnascida e já órfã de pai. Era Dona Aidée, que veio ao mundo às vésperas do Natal, no dia 20 de dezembro, no mesmo ano da morte de seu pai. Sua família tornarase o que os sociólogos Francisco Foot Hardman e Victor Leonardi (1982, p. 199) designam como um agregado da fábrica.

Mesmo assim, a mãe de Dona Aidée não encontrou sossego para sua angústia e tristeza. Manteve-se na melancolia diante da perda do marido. "A minha mãe nunca parava de chorar quando ela contava para gente já grande. Ela não suportava, então quase perdia a visão de chorar todos os dias." Anos depois, Dona Aidée, já adolescente, passou a trabalhar na Fábrica Carmen.

O choro da mãe de Aidée, decorrente do sofrimento pela perda do marido, pode também expressar o choro de outras famílias que tiveram vidas ceifadas por acidentes de trabalho. A vida, diante dos perigos que o trabalho fabril oferecia, tornava-se incerta nessa vila operária, possibilitando o desamparo pela perda, a tristeza, a melancolia. Mesmo nas gestões seguintes, quando houve maior preocupação dos patrões com a condição do corpo produtivo e a regulamentação das leis do trabalho, que poderiam amparar os trabalhadores, os acidentes continuaram ocorrendo. "Houve aqui uma vez uma explosão na Fábrica que matou um. Foi no setor de engomadeira. A engomadeira explodiu e matou um cidadão. Faz muitos anos. Foi mais ou menos em 1950", lembrou Zequinha Moura (2014) sobre os tempos da Fábrica Carmen.

Uma situação, entre tantas outras, que representa as duras condições de trabalho nessa Vila Operária e Fábrica no passado, muitas vezes invisíveis entre festas, algumas ações e benefícios sociais que favoreciam a produção de uma imagem benevolente dos patrões. Eram condições de vida e de sofrimento quase sempre insuperáveis pelos operários. Ou, quando insuportáveis, ensejavam resistências como formas de sobrevivência em meio aos precipícios da produção 
capitalista que, ao ofertar assistências aos operários, também hipotecavam sua liberdade, mantendo sua vida incerta em meio aos perigos durante a produção fabril.

\section{As representações operárias e os espaços institucionais e informais de resistência}

Contrapondo-se aos perigos do trabalho, as resistências operárias ocorriam individualmente com trampolinagens e dribles, mas também coletivamente, seja nos espaços institucionais ou de forma espontânea e informal.

Em 1930, foi criado, por Getúlio Vargas, o Ministério do Trabalho, Indústria e Comércio. A denominação desse órgão permite perceber a importância que as questões trabalhistas passaram a ter no âmbito estatal. O trabalho era tratado no mesmo conjunto de políticas para a indústria e comércio, sendo então debatidos e propostas ações que os relacionavam. Esse Ministério, o Decreto-Lei n.01402/39 que regulamentava a fundação e o funcionamento dos sindicatos no país, a instalação da Justiça do Trabalho em 1941 e a promulgação da Consolidação das Leis do Trabalho (CLT) em 1943, compunham as políticas trabalhistas de Getúlio Vargas (1930-1945), sobretudo após o Estado Novo (1937).

O Sindicato dos Trabalhadores na Indústria de Fiação e Tecelagem de Fernão Velho foi criado em 1939. Propunha-se a defender os interesses dos trabalhadores daquela localidade, além de adequar-se à legislação trabalhista. Destaco nesse cenário, a relevância da regulamentação sindical e da CLT como instrumentos que permitiriam controle sobre os movimentos de trabalhadores. Instituía-se no Brasil o que a historiadora Angela de Castro Gomes (2005) designou como sindicalismo corporativista. O Estado Novo (1937-1945) se apropriava da palavra dos trabalhadores, passando a tutelar a questão social e trabalhista no país. Antes mesmo de qualquer reivindicação, o Estado reconhecia as demandas sociais como uma necessidade ao bem-estar do trabalhador, e desse modo "concedia benefícios" na forma de legislação social. Estabelecia-se com essa relação entre Estado e trabalhadores uma troca simbólica entre o 
controle e o gozo de benefícios sociais. Como retribuição pelos direitos sociais, o trabalhador devia moralmente a obediência política.

Fortalecendo essa obediência, o trabalhador apenas teria seus direitos garantidos se fosse sindicalizado. Prevalecia uma lógica de que "quem tem ofício, tem benefício" (GOMES, 2005, p. 175), criando brechas para o forte controle estatal sobre o trabalhador por meio dos sindicatos, constituindo assim um sindicalismo corporativista em favor dos interesses daqueles que compunham o Estado. Visava-se quebrar a autonomia dos sindicatos, submetendo-os às rígidas regras estatais para que tivessem legitimidade jurídica e política.

O reconhecimento e outorga para funcionamento era concedido pelo Ministério do Trabalho, Indústria e Comércio. O que não significou necessariamente que os sindicatos fossem imunes ao desejo de luta por direitos e melhores condições de vida, ou mesmo à influência de militantes que não aderiam à cartilha dos interesses do Estado e do segmento patronal. Ao contrário, apesar de toda tentativa de controle, é possível perceber nessas instituições brechas para autonomia dos interesses dos trabalhadores.

O Sindicato dos Trabalhadores na Indústria de Fiação e Tecelagem de Fernão Velho era um dos maiores em Alagoas e é plausível que nos anos 1940 já tivesse acumulado práticas de outras formas de organização de classe ${ }^{24}$. Muitos operários procuravam o sindicato não apenas para reivindicar direitos e denunciar os patrões. Buscavam assistência de diversos tipos: auxílio financeiro para medicamentos, material escolar, serviços odontológicos, entre outros. Era um espaço institucional e político, podendo inclusive render prestígio às suas lideranças.

Conforme se pode observar nas Atas do Sindicato ${ }^{25}$, a eleição para composição de sua diretoria ocorria de dois em dois anos. A posse dos novos

\footnotetext{
${ }^{24}$ Cita-se como exemplo de organização de classe anterior ao sindicato, a Sociedade Beneficente de Proteção e Auxílio da Companhia União Mercantil, criada em meados dos anos 1870. Para o historiador Oswaldo B. Acioly Maciel (2010), trata-se de pioneira organização de classe no segmento têxtil no estado, e que teve relevante papel na construção histórica de uma cultura operária. Inclusive com competência para acolher reclamações de seus associados, o que possibilitava mobilizações em torno de interesses comuns.

${ }^{25}$ Para maiores informações, ver: SINDICATO DOS TRABALHADORES NA INDÚSTRIA DE FIAÇÃO E TECELAGEM DE FERNÃO VELHO. In: LIVRO DE ATAS. Maceió: [o Sindicato], 1953-1964.
} 
diretores e presidente era sempre motivo de cerimônia solene. Geralmente, contava com a presença do governador e/ou representantes do Estado, deputados, membros de outros sindicatos, padres e, por vezes, até representantes da polícia. Um operário, quando eleito como presidente desse órgão de classe, passava a gozar de alguns privilégios, a exemplo do uso de redes políticas.

No entanto, nem sempre eram eleitos representantes comprometidos plenamente com os operários. Havia pressão para eleger candidatos que fossem mais suscetíveis ao diálogo, menos radicalismo, e até mesmo próximos aos interesses patronais, podendo receber boa contrapartida financeira da Fábrica. Além do que, o eleito também poderia controlar os recursos financeiros advindos do imposto sindical, entre outros.

A Caixa Beneficente foi criada posteriormente, em 1942. Enquanto o sindicato se voltava para as questões políticas e de direitos, a Caixa Beneficente atuava no amparo aos seus associados. Oferecia auxílio funeral, complementação de assistência médica, reforço escolar, entre outros. Muitos operários, mesmo depois de aposentados, continuavam contribuindo com cotas mensais de modo a assegurar o direito aos serviços. Muitos líderes operários atuaram nas duas organizações de classe.

Na tentativa de fugir das possibilidades de controle dentro do sindicato e assegurar maior autonomia nas suas lutas, os operários em Fernão Velho também se reuniam em uma espécie de fórum informal sem diretoria ou sede. Tratava-se do que os operários designavam "Senado". Para o historiador Ivo dos Santos Farias (2014, p.140), consistia em uma organização "extra-institucional". Essa configuração visava tentar se desgarrar do controle patronal e estatal que em diversos momentos poderia interferir nas decisões do Sindicato. Funcionava na praça, debaixo de uma árvore ou em volta de bancos. Os operários se reuniam para conversar. Enquanto jovens e adultos se encontravam para discutir sobre futebol e assuntos frívolos, outro grupo se camuflava no espaço de uso coletivo para discutir e compartilhar insatisfações contra as determinações da Fábrica. 
Esse segundo grupo acolhia os operários de comportamento arredio, homens mais velhos, entre outros.

O Senado era um espaço alternativo, mais fluido e escorregadio onde se driblava o controle. Era até plausível que algumas propostas apresentadas nas reuniões do sindicato tenham sido discutidas e formuladas antecipadamente no Senado (FARIAS, 2014). Uma experiência que vislumbra reconhecer que os desígnios de controle estatal dos movimentos de trabalhadores a partir do Estado Novo não eram imunes ao protagonismo dos operários. Estes encontravam brechas dentro e fora dos sindicatos para se organizarem, exercerem sua autonomia de ação nas lutas políticas que se sucediam.

O Sindicato, o Senado e a Caixa Beneficente encampavam lutas pelos direitos daqueles que representavam. As tensões existentes nas relações de trabalho em Fernão Velho eram permanentes e aumentavam diante de uma vida incerta na produção ao rés do chão da fábrica.

Visando a produtividade, o Grupo Othon, por outro lado, promoveu reformas em algumas seções da Fábrica Carmen, instalando modernos maquinários, entre outros incrementos para a produção, a exemplo dos aspersores da seção de tecelagem. Em 1962, instalaram novas máquinas de tecelagem e passaram a exigir que as tecelãs manipulassem um número maior de teares, passando de quatro para seis. Essa situação gerou insatisfação entre os operários, sentimento esse reforçado pela defasagem salarial e crise econômica no período. As operárias buscaram a mediação do sindicato conforme se pode observar na Sessão Ordinária do dia 19 de agosto de $1962^{26}$.

Nesse dia, os operários e seus representantes de classe se reuniram na sede social do sindicato. Discutiram sobre a situação a que as tecelãs vinham sendo submetidas. Essas mesmas tecelãs se recusavam a manipular um número maior de teares sem que houvesse um reajuste salarial. Nesse impasse, denunciavam o aumento da produtividade e o lucro exacerbado para a Fábrica, que, por sua vez, mantinha os mesmos salários. Os trabalhadores não teriam vantagens nessa nova condição, tanto pela manipulação de mais teares, como

${ }^{26}$ SINDICATO DOS TRABALHADORES NA INDÚSTRIA DE FIAÇÃO E TECELAGEM DE FERNÃO VELHO. Ata de sessão ordinária de 19 de agosto de 1962. In: LIVRO DE ATAS. Maceió: [o Sindicato], 1953-1964. 
por novos e modernos maquinários que empreendem um menor tempo na produção, fomentando, assim, maior produtividade durante a jornada de trabalho.

Nessa reunião, a deliberação não foi pela deflagração de greve. Contudo, buscava-se, ainda, manter aberto o diálogo com os patrões a fim de uma solução para o impasse. As tecelãs concordaram que trabalhariam até uma quarta-feira, dia 22 de agosto daquele ano de 1962, aguardando o posicionamento dos patrões sobre suas propostas. Tentativas de negociação como essa não era um caso isolado de Fernão Velho. Nesse mesmo ano, diversos sindicatos já vinham encampando lutas pelo aumento do salário mínimo e contra a carestia do custo de vida, sendo frequentemente noticiada no jornal comunista $A$ voz do povo.

No dia 22 de agosto, outra reunião do sindicato foi realizada. Um dos operários se queixou de que o custo de vida já comprometia mais de $75 \%$ de seu salário. O que melhoraria a situação não seria mais o pagamento pela manipulação dos novos teares, mas o atendimento total às suas reivindicações ${ }^{27}$. Os administradores da Fábrica pediram um prazo de trinta dias para a análise das reivindicações, porém já havia uma espera de três dias. No fim dessa reunião, a assembleia sindical definiu o prazo de quarenta e oito horas para que os proprietários pudessem avaliar o pleito dos operários.

Diante do impasse, também foram mobilizados dispositivos repressores do Estado. "Inesperadamente, e para surpresa de todos, carros da Rádio Patrulha estiveram durante a segunda e terça-feira passadas em Fernão Velho, como que à espera de algo de anormal ou para coagirem as operárias” (OPERÁRIOS..., 1962, p. 4). Essa situação foi noticiada pelo jornal Gazeta de Alagoas de modo a produzir um cenário de periculosidade. Justificava a presença da força policial para proteger as instalações da Fábrica Carmen e coibir violentamente os trabalhadores em caso de confronto.

O jornal Gazeta de Alagoas continuou acompanhando e noticiando a greve. Informou ${ }^{28}$ que a direção da Fábrica Carmen continuava a insistir na manutenção da manipulação de seis teares, e justificara que essa situação já era aceito e

\footnotetext{
${ }^{27}$ Era comum entre várias categorias profissionais, nesse período, o pleito de aumento de $40 \%$ nos salários para repor as perdas da elevação do custo de vida.

28 Para maiores informações, ver: OTHON BEZERRA DE MELLO, FIAÇÃO E TECELAGEM S/A. Esclarecimento de autoridades e ao público em geral. Gazeta de Alagoas, Maceió, 26 ago. 1962.
} 
praticado na rotina de produção dos operários porque possibilitavam maior salário. Mesmo assim, tentando resolver o impasse, a representação patronal propôs a manipulação de cinco teares, o que não agradou aos operários. Eles não aceitaram, culminando na paralisação do setor de tecelagem (TAVARES, 2014). Com esse ato, que tinha as mulheres tecelãs como principais protagonistas, outros setores da Fábrica Carmen também paralisaram, configurando uma greve geral em Fernão velho.

\section{Entre tecituras e tramas: algumas considerações à guisa de conclusão}

Nas tecituras do trabalho operário em Fernão Velho, Alagoas, diversos fios foram puxados e urdidos nessa narrativa: a produção têxtil, o próprio trabalho operário, a insegurança presente na fabricação de linhas e tecidos, as representações de classe sejam institucionais ou informais, e as próprias resistências de trabalhadores.

Ganhou centralidade nessa análise, o cotidiano na Fábrica Carmen, sendo este marcado por situações de periculosidade para seus operários, permitindonos cotejar uma representação de vida incerta em meio às máquinas no interior de suas instalações. Os riscos de acidentes de trabalho, as condições de insalubridade com temperaturas e ruídos inadequados ao corpo humano, e a intensificação da produção como uma das expressões da exploração capitalista, denotam a tragicidade do trabalho fabril. São situações próprias da experiência operária, embora não devam ser naturalizadas.

O modelo de fábrica com vila operária (STEIN, 1979), com as formas de assistência patronal, e o trabalho urbano com previsão de direitos trabalhistas, não configuravam sentimentos e comportamentos conformistas entre os operários. Nem tampouco satisfação plena com suas condições de vida e trabalho. Longe disso, esses operários e operárias resistiam em seu cotidiano de sobrevivência, lutando contra as diversas condições que colocavam suas vidas em estados de incertezas, seja da vulnerabilidade que estavam à mercê nas suas atividades laborais, seja no dolo diante da negação patronal de direitos, inclusive o da dignidade. 
Em diversas situações-limite, atuaram individualmente e/ou coletivamente. Muitas vezes denunciavam sua vida incerta nos órgãos de classe operária, a exemplo do Sindicato. Articulavam greves, driblavam a disciplina patronal e debatiam suas demandas no Senado, moviam reclamações trabalhistas, entre outras formas de resistência. Se por um lado se constata experiências trágicas nesse trabalho, por outro, há de se reconhecer as possibilidades de sobrevivência, do sustento dos operários e suas famílias.

O caso de João Verçosa de Aguiar é exemplar das trampolinagens, receios, angústias e viradas de jogo. Contra o risco de demissão motivada por suas faltas decorrentes de enfermidade contraída no trabalho, buscou a mediação do Sindicato. Sofria com uma hérnia que the acometia e deixava acamado. E estava sob o risco de ser demitido por justa causa, podendo perder o trabalho, o salário, e a moradia, colocando sua própria família em risco. Conseguiu comprovar, por meio de exames e saberes médicos, o dano que o trabalho fabril causara ao seu corpo. Com a atuação de seu Sindicato, forçou outra postura por parte da Fábrica Carmen. Esta se dispôs a arcar com a cirurgia médica necessária, que fora o tratamento indicado para esse operário.

O afastamento prévio e unilateral de João Verçosa, motivador da ação de demissão pela Fábrica Carmen, não era resultado de uma postura desidiosa desse operário. Mas era, sim, uma postura necessária para recuperar seu bom estado de saúde, permitindo-lhe também que se tornasse novamente um corpo produtivo. Na medida em que os patrões custearam a intervenção médica em seu corpo, caberia ao Sindicato o pagamento de um benefício enquanto estivesse afastado do trabalho. Enquanto isso, seu salário na Fábrica estaria suspenso, gerando ainda mais angústia ao operário. Não pela cirurgia a que seria submetido, mas pela incerteza da manutenção de sua família enquanto estivesse incapacitado para o trabalho.

Uma situação que, segundo a filósofa Hannah Arendt (2014), poderia se expressar como sendo um "metabolismo do homem com a natureza" em que a produção material é ajustada às necessidades do trabalhador, e acrescento, à sua família. O trabalho é incorporado a esse sujeito como parte de seu ciclo de 
vida biológico, porém sustentado pelo consumo de tudo aquilo que provém: alimentar-se, morar, vestir-se... Ou noutros termos:

Tudo o que o trabalho produz destina-se a alimentar quase imediatamente o processo da vida humana, e esse consumo, regenerando o processo vital, produz - ou antes, reproduz - nova força de trabalho de que o corpo necessita para seu posterior consumo. (ARENDT, 2014, p. 122)

Agravando ainda mais sua situação, João Verçosa se desentendeu com José Conrado, então presidente do Sindicato. Esse fato provocara a suspensão de seu benefício. O operário sugeria que o custo da intervenção médica fosse convertido em auxílio pela empresa. Rubem Ângelo, o advogado sindical, não concordou com essa sugestão. Alertou que caso o tratamento fosse transformado em auxílio, poderia incorrer na sua não realização. O dinheiro acabaria e o operário continuaria incapacitado, inclusive para ingressar em outro emprego e/ou atividade.

O operário estava próximo de conquistar a aposentadoria. O presidente do Sindicato então concordou em encaminhar uma solicitação à Fábrica sugerindo reintegrá-lo em uma função que, diante de seus limites de saúde, pudesse exercer. Assim poderia evitar que sua família ficasse desamparada. No entanto, o advogado propôs a continuidade do auxílio pelo Sindicato, o que foi submetido à votação de seus membros. Essa última proposta foi aprovada.

Quanto às medidas de modernização do parque fabril, com investimentos na compra de maquinários, a Fábrica Carmen promovia uma escalada da exploração do trabalho operário, visando potencializar a produtividade e o lucro. A greve das tecelãs em 1962 demonstra a forte capacidade de articulação e engajamento desses operários têxteis na luta contra situações-limite e de vida incerta.

Após três dias de greve, a Fábrica Carmen e os operários firmaram um acordo. As tecelãs conseguiram manter a manipulação de quatro teares. Lutavase também nesse movimento, pelo aumento salarial necessário para suprir as perdas econômicas provocadas pela constante elevação do custo de vida no país no início dos anos 1960. A reclamação das tecelãs que se tornara o estopim para 
a deflagração de uma greve capaz de paralisar toda a fábrica, produzia efeitos além dos limites de Fernão Velho naquele presente de 1962. Repercutiu em outras fábricas, servindo de exemplo e motivando outras paralisações. Foi noticiada pela grande imprensa no estado, pelos jornais Gazeta de Alagoas e Jornal de Alagoas. Tornou-se o movimento grevista mais lembrado entre os operários de Fernão Velho.

Há de se reconhecer nas diversas situações operárias aqui narradas, o próprio acontecimento de se tornar operário como experiência histórica do trabalho. E nesse caso, é também urdido nas resistências contra as situações que colocavam a própria vida em estado de incerteza, seja pela insalubridade no trabalho e sua exploração. Fatores que potencializam os protagonismos de homens e mulheres nas lutas por dignidade, direitos e cidadania. E fazem emergir uma cultura de classes, em meio ao cotidiano fabril, permeado por expectativas e sonhos dos operários e operárias diante dos seus dilemas existenciais. Tecendo todos esses fios, enseja-se compreender historicamente, as tramas presentes no trabalho e na produção têxtil, lançando esclarecimentos não apenas para Fernão Velho e a Fábrica Carmen, mas quiçá outras configurações históricas e do trabalho semelhantes.

\section{Referências}

ARENDT, Hannah. A condição humana. 12. ed. Rio de Janeiro: Forense Universitária, 2014.

BENJAMIN, Walter. O narrador: considerações sobre a obra de Nikolai Leskov. In: BENJAMIN, Walter. Obras escolhidas: magia e técnica, arte e política: ensaios sobre literatura e história da cultura. 3. ed. São Paulo: Brasiliense, 1994a. v.1.

BENJAMIN, Walter. A imagem de Proust. In: BENJAMIN, Walter. Obras escolhidas: magia e técnica, arte e política: ensaios sobre literatura e história da cultura. 3. ed. São Paulo: Brasiliense, 1994b. v.1.

BENJAMIN, Walter. Experiência e pobreza. In: BENJAMIN, Walter. Obras escolhidas: magia e técnica, arte e política: ensaios sobre literatura e história da cultura. 3. ed. São Paulo: Brasiliense, 1994c. v.1. 
BRASIL. Tribunal Superior do Trabalho. A justiça do trabalho entre dois extremos: reflexões sobre sua instalação. [Brasília: TST, 20--]. Disponível em: http://www.tst.jus.br/historia-da-justica-do-trabalho. Acesso em: 6 nov. 2013.

CALVINO, Ítalo. As cidades invisíveis. São Paulo: Companhia das Letras, 1991.

CARACCIOLO, Carlos. [Entrevista cedida a] Marcelo Góes Tavares, Maceió (AL), 11 set. 2015.

CARDOSO, Antônio. [Entrevista cedida a] Marcelo Góes Tavares, Maceió (AL), 15 set. 2015.

CIPRIANO, Waldir. Fernão Velho: tradição e história. O Jornal, Maceió, 17 jan. 1999. Caderno de Cultura, p. 5.

COMPANHIA UNIÃO MERCANTIL. Seção de Tecelagem. Fernão Velho-AL, [19--?]. Imagem n. 177, Pasta 07 - Postais de Maceió.

COMPANHIA UNIÃO MERCANTIL. Relatório da Companhia União Mercantil para ser apresentado à assembleia geral dos acionistas em 06 de março de 1911. In: RECORTES DO DIÁRIO OFFICIAL DO ESTADO DE ALAGOAS. Maceió: Instituto Histórico e Geográfico de Alagoas, [19--]. 1 v.

COMPANHIA UNIÃO MERCANTIL, Relatório dos negócios sociaes da Companhia União Mercantil, relativos ao anno de 1929, para ser apresentado em Assembléia Geral de Accionistas no dia 17 de março de 1930. Diário Official de Alagoas. Maceió: Governo do Estado de Alagoas, 18 mar. 1930. p. 05-06.

COMPANHIA UNIÃO MERCANTIL. Relatório dos negócios sociaes da Companhia União Mercantil, relativos ao anno de 1930, para ser apresentado em Assembléia Geral de Accionistas no dia 27 de março de 1931. Diário Official de Alagoas. Maceió: Governo do Estado de Alagoas, 26 mar. 1931. p. 05.

COMPANHIA UNIÃO MERCANTIL. Edital. Diário Oficial de Alagoas. Maceió: Governo do Estado de Alagoas, 27 mar. 1940. p.10.

COMPANHIA ALAGOANA DE FIAÇÃO E TECIDOS. Relatório da Diretoria a ser apresentado a Assembléia Geral Ordinária de Acionistas, convocada para 31 de março de 1948. Diário Official de Alagoas. Maceió: [s.n.], 30 mar. 1948.

CORREIA, Telma de Barros. Pedra: plano e cotidiano operário no sertão. Campinas: Papirus, 1998.FÁBRICA CARMEN FIAÇÃO E TECELAGEM S/A. Prospecto de demonstração de tecidos. [Maceió: A FÁBRICA, 1997]. 
DONA AIDÉE. Relato. In: LESSA, Golbery. Trama da memória, tessitura do tempo: registro da memória e da iconografia das famílias de tradição operária residentes no bairro de Fernão Velho, Maceió, AL. Coordenação de Analice Dantas Santos e Golbery Lessa. Maceió: Universidade Estadual de Ciência da Saúde de Alagoas, 2008. 1 DVD, son., color. Documentário.

FARIAS, Ivo dos Santos. Nossa casa é do patrão: dominação e resistência operária no núcleo fabril de Fernão Velho, Maceió, AL. Curitiba: Appris, 2014.

FERREIRA, Veríssimo. História de Fernão Velho. Maceió: [s.n.], 1997. Mimeografado.

FRANCO, Tânia Maria de Almeida. O processo de trabalho na indústria têxtil: um estudo de caso. Dissertação (Mestrado em Ciências Sociais) - Faculdade de Filosofia e Ciências Humanas, Universidade Federal da Bahia, Salvador, 1983.

GOMES, Angela de Castro. A invenção do trabalhismo. 3. ed. Rio de Janeiro: FGV, 2005.

HARDMAN, Francisco Foot; LEONARDI, Victor. História da indústria e do trabalho no Brasil: das origens aos anos vinte. São Paulo: Global, 1982.

LOPES, José Sérgio Leite. A tecelagem do conflito de classes na cidade das chaminés. São Paulo: Marco Zero; Brasília: Editora da UnB, 1988.

MACIEL, Osvaldo Batista Acioly. Estatutos de Sociedades Mutualistas e a história social do trabalho: conjecturas em torno da Sociedade Beneficente de Proteção e Auxílio da Companhia União Mercantil, Fernão Velho, 1876-1879. Revista Crítica Histórica, Maceió: CPDHis: UFAL, ano 1, n. 1, jun. 2010. Disponível em: http://www.revista.ufal.br/criticahistorica/attachments/article/61/Estatutos\%20d e\%20Sociedades\%20Mutualistas.pdf. Acesso em: 13 jun 2013.

MARROQUIM, Adalberto. Terra das Alagoas. Maceió: Grupo João Lyra, 2000. Edição fac-similar de 1922.

MELLO, Juçara da Silva Barbosa de. Fios da rede: industrial e trabalhadores na criação e expansão de um grupo empresarial (1920-1949). 2012. Tese

(Doutorado em História) - Programa de Pós-Graduação em História Social da Cultura, Centro de Ciências Sociais, Pontifícia Universidade Católica do Rio de Janeiro, Rio de Janeiro, 2012.

MEMÓRIA da vida e do trabalho. Direção e produção de Celso Brandão. Roteiro: Regina Coeli. Argumento e texto: José Sérgio Leite Lopes e Rosilene Alvim. Maceió: Estrela do Norte, 1986. 1 DVD (20 min), son., color. Documentário. 
MOURA, Zequinha Moura. [Entrevista cedida a] Marcelo Góes Tavares, Maceió (AL), 23 jan. 2014.

OLIVEIRA, Gladson Macedo de. A Fábrica Maria Amália e sua inserção na cidade de Curvelo: os caminhos do desenvolvimento de uma indústria têxtil no interior de Minas Gerais, 1941-1992. 2007. Dissertação (Mestrado em Ciências Sociais) Programa de Pós-Graduação em Ciências Sociais, Pontifícia Universidade Católica de Minas Gerais, Belo Horizonte, 2007.

OPERÁRIOS de Fernão Velho em questão com a fábrica. Gazeta de Alagoas, Maceió, 25 ago. 1962. n.p.

OPERÁRIOS na seção de tecelagem em Fernão Velho. In: MARROQUIM, Adalberto. Terra de Alagoas. [S.l.: s.n.], 1922.

OTHON BEZERRA DE MELLO FIAÇÃO E TECELAGEM S/A. Esclarecimento de autoridades e ao público em geral. Gazeta de Alagoas, Maceió, 26 ago. 1962.

PAULINO, Luiz. [Entrevista cedida a] Marcelo Góes Tavares, Maceió (AL), 28 out. 2014.

POLLAK, Michael. Memória, esquecimento, silêncio. Revista Estudos Históricos, Rio de Janeiro, v. 2, n. 3, p. 3-15, 1989.

PROCESSO JCJ n.o 594/59, Justiça do Trabalho, Junta de Conciliação e Julgamento, 6. . Região.

RAGO, Margareth. Do cabaré ao lar. a utopia da cidade disciplinar: Brasil 18901930. Rio de Janeiro: Paz e Terra, 2014.

RICOEUR, Paul. A memória, a história, o esquecimento. Campinas: Ed. Unicamp, 2007.

SANT'ANA, Moacir Medeiros de. Algodão: cultivo e indústria. In: SANT'ANA, Moacir Medeiros de. Contribuição à história do açúcar. Maceió: Imprensa Oficial Graciliano Ramos, 2011.

SINDICATO DOS TRABALHADORES NA INDÚSTRIA DE FIAÇÃO E TECELAGEM DE FERNÃO VELHO. Ata de sessão ordinária de 22 de abril de 1953. In: LIVRO DE ATAS. Maceió, [o Sindicato], 1953-1964.

SINDICATO DOS TRABALHADORES NA INDÚSTRIA DE FIAÇÃO E TECELAGEM DE FERNÃO VELHO. Ata de sessão ordinária de 02 de dezembro de 1953. In: LIVRO DE ATAS. Maceió, [o Sindicato], 1953-1964. 
SINDICATO DOS TRABALHADORES NA INDÚSTRIA DE FIAÇÃO E TECELAGEM DE FERNÃO VELHO. Ata de sessão ordinária de 19 de agosto de 1962. In: LIVRO DE ATAS. Maceió, [o Sindicato], 1953-1964.

SOUZA, Emília de. [Entrevista cedida a] Marcelo Góes Tavares, Maceió (AL), 30 set. 2014.

STEIN, Stanley J. Origens e evolução da indústria têxtil no Brasil, 1850-1950. Rio de Janeiro: Campus, 1979.

TAVARES, Marcelo Góes. Do tecer da memória ao tecido da história: operários, trabalho e política na indústria têxtil de Fernão Velho (1943-1961). 2016. Tese (Doutorado em História) - Centro de Filosofia e Ciências Humanas, Universidade Federal de Pernambuco, Recife, 2016.

TAVARES, Marcelo Góes. Territórios fabris no ramo têxtil em Alagoas e fisiografias urbanas em Maceió (1857-1943): histórias e representações. Confins, [São Paulo], v. 40, maio 2019. Disponível em: http://journals.openedition.org/confins/20309. Acesso em: 01 jun. 2020.

TAVARES, Marcelo Góes. Vila fabril, território febril: cartografia de uma greve em Fernão Velho nos idos e vindos de 1962. In: CAVALCANTI, Erinaldo; CABRAL, Geovanni. A história e suas práticas de escrita: narrativas e documentos. Recife: Editora UFPE, 2014.

VALDICLEIDE. [Entrevista cedida a] Marcelo Góes Tavares, Maceió (AL), 24 jan. 2014. 